\title{
Socioeconomic status as an independent predictor of physiological biomarkers of cardiovascular disease: Evidence from NHANES
}

\author{
Peter Muennig $^{\mathrm{a}, *}$, Nancy Sohler ${ }^{\mathrm{b}}$, Bisundev Mahato ${ }^{\mathrm{a}}$ \\ ${ }^{a}$ Mailman School of Public Health, Columbia University, New York, NY 10032, USA \\ ${ }^{\mathrm{b}}$ City University of New York Medical School, New York, NY 10031, USA
}

Available online 24 April 2007

\begin{abstract}
Background. C-reactive protein, homocysteine, cholesterol, and fibrinogen are known to vary by socioeconomic status (SES). Using a nationally representative study, we examined whether these factors vary independently of all other known risk factors, such as diet, exercise, and genetic predisposition.

Methods. We analyzed the 1999-2002 National Health Examination and Nutrition Survey using logistic regression models.

Results. We found that high-density lipoprotein cholesterol blood levels increase with income and educational attainment after controlling all known risk factors for elevated cholesterol (e.g., diet, exercise, and family history). Blood levels of C-reactive protein are inversely associated with income and education. Homocysteine blood levels are inversely associated with income even after controlling for blood folate level. A nonsignificant inverse relationship between homocysteine levels and educational attainment was also observed. Blood levels of low-density lipoprotein cholesterol and fibrinogen were not significantly associated with income or education.

Conclusions. Levels of "good" (high density lipoprotein) cholesterol increase with income and education even after controlling for factors known to place people at risk of high cholesterol. Stress differences by social class may play a role.

(C) 2007 Elsevier Inc. All rights reserved.
\end{abstract}

Keywords: Socioeconomic factors; Stress; Cholesterol

\section{Introduction}

The wealthiest Americans are at lower risk of disease and death than any other income group in the United States; relative to the wealthiest $20 \%$ of Americans, the remainder of the United States population experiences 861,000 excess deaths, resulting in 14 million years of perfect health lost each year (Muennig et al., 2005). Higher death rates among those in abject poverty are partly due to obvious risk factors such as crime and poor housing (Ross and Mirowsky, 2001). However, higher death rates among the middle classes (relative to the upper classes) largely remain a mystery. The majority of these excess deaths are attributable to cardiovascular disease, cancer, infection, and diabetes; yet, higher rates of smoking and sedentary lifestyles

\footnotetext{
* Corresponding author. Columbia University, Department of Health Policy and Management, 600 W. 168th Street, 6th Floor, New York, NY 10032, USA. Fax: +1 2123053405 .

E-mail address: pm124@columbia.edu (P. Muennig).
}

among persons of lower SES may account for just $12-30 \%$ of these deaths (Lantz et al., 1998; Smith et al., 1990).

This has led to recent research efforts geared toward identifying other risk factors that might explain the higher rates of mortality among persons of lower socioeconomic status (SES). One candidate is psychological stress. People with lower educational attainment or income report significantly higher numbers of daily hassles and stressors than those with more education or income (Taylor, 2002).

Stress has been hypothesized to produce chronic dysfunction of the body's regulatory systems (Sterling and Eyer, 1988; McEwen, 1998). This chronic dysfunction is thought to affect the autonomic (fight or flight), metabolic, and immune systems, as well as the hypothalamic-pituitary-adrenal axis, which is responsible for maintaining cortisone levels. Finally, this cascade produces oxidative stress that may accelerate cell aging (Epel et al., 2004; Irie et al., 2002; Cherkas et al., 2006).

Blood levels of the biochemicals associated with the stress response (e.g. cortisol, C-reactive protein, and fibrinogen) are 
thought to be higher among persons of lower SES over the life course (Steptoe et al., 2002a,b; Goodman et al., 2005; Ridker et al., 2000). Cholesterol may vary by SES (Wamala et al., 1999; Pfohl et al., 1999). For instance, experimental manipulation of social position within primate hierarchies results in adverse changes in primates' cholesterol profiles (Sapolsky, 2005).

Some of these substances may be atherogenic or carcinogenic, and some are immunomodulators. Therefore, they plausibly collectively explain the increased risk of cardiovascular disease, diabetes, and possibly even cancer among persons of low SES, which account for roughly $66 \%$ of the SES-related deaths annually (Wong et al., 2002).

However, it is not clear whether these substances are directly related to the pathophysiology of SES-associated medical conditions or serve as biomarkers for other deleterious physiological processes, risky health behaviors, or genetic effects (Davey Smith et al., 2004). In this study, we examine whether cholesterol levels, fibrinogen, homocysteine, and C-reactive protein vary independently of known behavioral and genetic risk factors using a comprehensive cross-sectional data set, the National Health and Nutrition Examination Survey (NHANES).

\section{Methods}

We examined the 1999-2002 NHANES, a representative cross-sectional survey of 21,004 persons of all ages in the United States (NCHS, 2005). This survey contains a sub-sample of 19,759 persons who were examined medically. In addition to a physical examination and food consumption interview, laboratory tests were obtained on sub-samples of the cohort. The population size tested for blood values of stress mediators and cholesterol varies depending on the test. For instance, most tests were administered to subjects over the age of 3 , but serum fibrinogen sub-sample was limited to persons over the age of 40 . Table 1 lists the sample size by variable after excluding missing values.

Starting in 1999, the NHANES has been conduced on an ongoing basis. The present study examines data from the first 4 years of data collection. It includes only those subjects who were examined medically and had laboratory tests. The study employs a complex sampling design consisting of sampling at the county, household, and individual levels. Each year, specific sub-groups are oversampled including low-income whites in 2000, and blacks and Mexican Americans in other years. The NHANES protocol was approved by a governmental Institutional Review Board. All subjects were financially compensated for participation in the study.

\section{Laboratory specimens}

Laboratory specimens were analyzed at Johns Hopkins Hospital. HDL cholesterol was measured using both a heparin-Mn preparation technique and by direct immunoassay. The heparin-Mn specimens were adjusted after quality control. Details of these corrections are available from the National Center for Health Statistics (National Health and Nutrition Examination Survey, 2005). High sensitivity C-reactive protein was measured using latex-enhanced nephelometry. Fibrinogen was measured via the Clauss clotting technique, and homocysteine was measured using the Abbott Homocysteine Assay. Homocysteine and fibrinogen specimens were frozen directly after collection.

\section{Statistical analyses}

Controlling for known covariates that might confound the relationship between the stress mediator levels and SES, we built seven logistic regression models (see Table 1 for the covariates included in each model). The first four models used HDL cholesterol, and LDL cholesterol as dependent variables. We dichotomized each dependent variable at the cut-off point generally considered to be an abnormally high value for each type of cholesterol. (In the HDL model, an
Table 1

Means of the dependent variables used in the analysis (columns) by each independent predictor (rows)

\begin{tabular}{|c|c|c|c|c|c|}
\hline \multirow[t]{2}{*}{ Covariate } & \multirow{2}{*}{$\begin{array}{l}\begin{array}{l}\text { HDL } \\
\text { cholesterol } \\
(\mathrm{mg} / \mathrm{dL})\end{array} \\
N=10,488^{*}\end{array}$} & \multirow{2}{*}{$\begin{array}{l}\begin{array}{l}\text { LDL } \\
\text { cholesterol } \\
(\mathrm{mg} / \mathrm{dL})\end{array} \\
N=4726^{*}\end{array}$} & \multirow{2}{*}{$\begin{array}{l}\text { C-reactive } \\
\text { protein } \\
(\mathrm{mg} / \mathrm{dL})\end{array}$} & \multirow{2}{*}{$\begin{array}{l}\begin{array}{l}\text { Fibrinogen } \\
(\mathrm{mg} / \mathrm{dL})\end{array} \\
N=5087^{*}\end{array}$} & \multirow{2}{*}{$\begin{array}{l}\text { Homocysteine } \\
(\mu \mathrm{mol} / \mathrm{dL})\end{array}$} \\
\hline & & & & & \\
\hline \multicolumn{6}{|l|}{ Income } \\
\hline$<20 \mathrm{~K}$ & 50.8 & 113.2 & 0.39 & 392.6 & 7.3 \\
\hline$\geq 20 \mathrm{~K}$ & 51.6 & 114.6 & 0.34 & 370.8 & 7.0 \\
\hline \multicolumn{6}{|c|}{ Education } \\
\hline$<\mathrm{HS}$ & 50.5 & 107.1 & 0.31 & 388.3 & 6.6 \\
\hline$\geq \mathrm{HS}$ & 52.4 & 122.2 & 0.45 & 372.2 & 8.2 \\
\hline \multicolumn{6}{|l|}{ Age } \\
\hline$<45$ & 51 & 106.7 & 0.27 & 347.3 & 5.9 \\
\hline$\geq 45$ & 52.1 & 127.8 & 0.56 & 384.8 & 9.9 \\
\hline \multicolumn{6}{|l|}{ Race } \\
\hline White & 51.4 & 110.7 & 0.35 & 381.8 & 6.7 \\
\hline Black & 51.2 & 118.9 & 0.37 & 375.2 & 7.8 \\
\hline \multicolumn{6}{|l|}{ Gender } \\
\hline Male & 48.0 & 114.5 & 0.29 & 369.9 & 7.7 \\
\hline Female & 54.5 & 113.9 & 0.42 & 386.7 & 6.5 \\
\hline \multicolumn{6}{|c|}{ Cotinine $(\mathrm{ng} / \mathrm{mL})^{\dagger}$} \\
\hline$<0.1$ & 51.9 & 114.5 & 0.35 & 375.8 & 6.9 \\
\hline$\geq 0.1$ & 50.2 & 113.2 & 0.37 & 384.7 & 7.6 \\
\hline \multicolumn{6}{|c|}{ Saturated fat $(\mathrm{gm})^{\ddagger}$} \\
\hline$<25$ & 51.5 & 115.2 & 0.40 & 384.2 & 7.2 \\
\hline$\geq 25$ & 50.9 & 113.1 & 0.30 & 367.1 & 6.8 \\
\hline \multicolumn{6}{|c|}{ Weekly exercise } \\
\hline Yes & 51.3 & 113.0 & 0.35 & 380.9 & 7.0 \\
\hline No & 51.9 & 117.8 & 0.40 & 366.0 & 7.5 \\
\hline \multicolumn{6}{|c|}{$\begin{array}{l}\mathrm{BMI} \\
\qquad\left(\mathrm{m} / \mathrm{kg}^{2}\right)\end{array}$} \\
\hline$\leq 30$ & 52.6 & 111.5 & 0.27 & 367.6 & 6.8 \\
\hline$>30$ & 46.8 & 132.3 & 0.65 & 393.4 & 7.9 \\
\hline \multicolumn{6}{|l|}{ Statins ${ }^{\pi}$} \\
\hline Yes & 51.5 & 114.0 & - & - & - \\
\hline No & 48.6 & 115.0 & - & - & - \\
\hline \multicolumn{6}{|c|}{ Country birth } \\
\hline US & 51.7 & 113.7 & 0.36 & 381.6 & 7.1 \\
\hline Other & 49.8 & 115.1 & 0.37 & 366.5 & 7.2 \\
\hline \multicolumn{6}{|c|}{ Family history heart disease } \\
\hline Yes & 50.4 & 117.0 & 0.57 & 399.1 & 9.9 \\
\hline No & 51.1 & 114.2 & 0.37 & 372.8 & 7.4 \\
\hline \multicolumn{6}{|c|}{ Folate $(\mathrm{ng} / \mathrm{mL})$} \\
\hline$<15$ & - & - & - & - & 7.6 \\
\hline$\geq 15$ & - & - & - & - & 6.3 \\
\hline
\end{tabular}

Means are unadjusted for any other covariate.

* The number of subjects varies from one variable to the next due to differences in sampling frame and missing values. The sample size represents the total subjects available for the column variable, but row means may contain lower sample sizes due to missing values.

${ }^{\dagger}$ Cotinine rounded to zero at two decimal places. Where it was non-significant, it was forced in the model.

${ }^{*}$ Trans fatty acids consumed in diet (g).

"Any HMG CoA reductase inhibitor, the medications most commonly prescribed for hypercholesterolemia.

abnormally high value is beneficial.) These were: HDL cholesterol $\geq 60 \mathrm{mg} / \mathrm{dL}$, and LDL cholesterol $\geq 100 \mathrm{mg} / \mathrm{dL}$.

The objective of the four cholesterol models was to examine the impact of measures of social class on cholesterol after controlling for known genetic and behavioral risk factors. The four cholesterol models therefore included the following independent variables: age (continuous in years), race (white vs. nonwhite), ethnicity (Hispanic vs. non-Hispanic), gender (male vs. female), body mass index (BMI) in $\mathrm{m} / \mathrm{kg}^{2}$, saturated fat consumption (gm), weekly exercise 
(yes vs. no), blood cotinine level as a measure of smoking in $\mathrm{ng} / \mathrm{mL}$, country of birth (US vs. elsewhere), use of HMG CoA-based cholesterol-lowering medications (any vs. none), and a family history of heart disease (yes vs. no).

Separate models were built that added either family income $(<\$ 20,000 \mathrm{vs}$. $\geq \$ 20,000)$ or education ( $\leq$ high school vs. $\geq$ high school) to the covariates above. Broader income intervals were available, but only on a smaller subsample of the cohort. We therefore conducted analyses using these broader intervals and the dichotomized income variable. We felt that the dichotomized variable was adequately robust, and chose this over the noisier estimate. To ensure that late high school graduates were captured, the education analysis included only subjects over the age of 25 . The regressions in which education was entered as a covariate therefore contained fewer subjects. Finally, because the strongest association was found between income and HDL cholesterol levels, we tested our hypothesis that these latter stress markers mediate the SESHDL cholesterol relationship.

The final three models included blood fibrinogen $(<300 \mathrm{mg} / \mathrm{dL}$ vs. $\geq 300 \mathrm{mg} / \mathrm{dL}$ ), C-reactive protein $(<1 \mathrm{mg} / \mathrm{L}$ vs. $\geq 1 \mathrm{mg} / \mathrm{L})$, and homocysteine $(<13 \mu \mathrm{mol} / \mathrm{L}$ vs. $\geq 13 \mu \mathrm{mol} / \mathrm{L})$ as dependent variables. The objective of this set of models is to ascertain whether blood markers of stress vary with social class independently of known risk factors. Each of these models therefore controlled for age, exercise, saturated fat consumption (used here as a proxy for dietary behaviors), blood cotinine levels, country of birth, and a family history of heart disease using the categories or ranges presented above. In addition, the model examining homocysteine levels controlled for serum folate levels.

Social support (number of friends) was initially included, but dropped out of all seven analyses and was excluded from all models $(p>0.15)$. Cotinine was borderline significant in some models, but was left in all models because it was felt to be an important variable.

All analyses were conducted using STATA 8.2 (College Station, TX), and accounted for the complex sample design employed in the NHANES. All dependent variables were tested using continuous values and simple linear regression. Models were then built using logistic regression to test whether the use of dichotomized dependent variables produced qualitatively different results. They did not, so we chose logistic regression in order to provide the general audience a more easily interpretable outcome measure, the odds ratio.

We assessed the goodness-of-fit of the logistic models using standard diagnostic procedures as outlined by Hosmer and Lemeshow (2000). In addition, prior to conducting the basic linear regressions described above, nondichotomized dependent variables were tested for linearity where appropriate.

\section{Results}

Table 1 shows the mean values of each independent variable by each dependent variable used in this analysis. Only the means for those variables included in each model are shown. High income, high education, younger age, white race, female gender, less exposure to smoke, less saturated fat, $\mathrm{BMI} \leq 30$, being foreign born, and having no family history of heart disease generally predicted more favorable blood levels of HDL cholesterol, CRP, fibrinogen, and homocysteine. However, some notable exceptions occurred. Foremost, those with low incomes, low educational attainment, or reporting weekly exercise had had similar or higher blood levels of LDL cholesterol relative to those with higher income, higher education, or non-exercisers.

Table 2 demonstrates the influence of each covariate on the complete multivariate models by income and education. Even after controlling for known risk factors for low HDL cholesterol (age, race, gender, smoking/second-hand smoke (cotinine), trans fat consumption, exercise, BMI, country of birth, and family history of heart disease), both income (odds ratio $[\mathrm{OR}]=1.40$ $[95 \% \mathrm{CI}=1.17,1.67])$ and education $(\mathrm{OR}=1.43[95 \% \mathrm{CI}=1.18$, 1.73]) remained significant predictors of higher HDL cholesterol levels.

The odds of elevated C-reactive protein levels in the blood were lower both for persons with higher educational attainment $(0.81 ; 95 \% \mathrm{CI}=0.67,0.97)$ and higher family income $(0.79$; $95 \% \mathrm{CI}=0.67,0.93)$. The odds of elevated homocysteine levels were significantly lower among persons with higher family income, but not for those with higher educational attainment. In the homocysteine model, the odds associated with high income were $0.52(95 \% \mathrm{CI}=0.36,0.77)$, even after controlling for serum folate (see Table 2). Fibrinogen levels showed a trend toward an inverse association with income and education, but the association was not statistically significant in this sample of persons over the age of 40 .

Table 3 shows the trend toward lower odds ratios for total cholesterol, and LDL cholesterol was noted among older age among persons with higher family income. Likewise, the odds ratios for beneficial HDL cholesterol levels increased with age among those with higher family income. However, including or excluding subjects under age 18 or limiting the analysis to subjects over 45 (the age range for which fibrinogen values

Table 2

Odds ratios for stress mediators by education and income

\begin{tabular}{|c|c|c|c|c|c|c|c|}
\hline & & $\begin{array}{l}\text { Income } \\
<\$ 20,000^{*},\end{array}$ & $\begin{array}{l}\text { Income } \\
\geq \$ 20,000 *, *\end{array}$ & $\begin{array}{l}\text { Odds ratio ( } 95 \% \\
\text { confidence limits) }\end{array}$ & $\begin{array}{l}\text { Education } \\
<\text { High school }^{\dagger, *}\end{array}$ & $\begin{array}{l}\text { Education } \\
\geq \text { High school }^{\dagger, *}\end{array}$ & $\begin{array}{l}\text { Odds ratio (95\% } \\
\text { confidence limits) }\end{array}$ \\
\hline \multirow[t]{2}{*}{ Low density lipoprotein } & $<100 \mathrm{mg} / \mathrm{dL}$ & 593 & 1195 & & 1096 & 691 & \\
\hline & $\geq 100 \mathrm{mg} / \mathrm{dL}$ & 919 & 2019 & $1.06(0.85,1.31)$ & 1228 & 1705 & $0.99(0.71,1.36)$ \\
\hline \multirow[t]{2}{*}{ High density lipoprotein } & $<60 \mathrm{mg}$ & 2801 & 5424 & & 4324 & 3891 & \\
\hline & $\geq 60 \mathrm{mg} / \mathrm{dL}$ & 696 & 1567 & $1.40(1.17,1.67$ & 949 & 1313 & $1.43(1.18,1.73)$ \\
\hline \multirow[t]{2}{*}{ C-reactive protein } & $<1 \mathrm{mg} / \mathrm{L}$ & 1245 & 2805 & & 2497 & 1549 & \\
\hline & $\geq 1 \mathrm{mg} / \mathrm{L}$ & 2262 & 4212 & $0.79(0.67,0.93)$ & 2794 & 3673 & $0.81(0.67,0.97)$ \\
\hline \multirow[t]{2}{*}{ Fibrinogen } & $<300 \mathrm{mg} / \mathrm{dL}$ & 821 & 2062 & & 958 & 604 & \\
\hline & $\geq 300 \mathrm{mg} / \mathrm{dL}$ & 574 & 898 & $0.81(0.64,1.01)$ & 1921 & 865 & $0.84(0.69,1.03)$ \\
\hline \multirow[t]{2}{*}{ Homocysteine } & $<13 \mu \mathrm{mol} / \mathrm{L}$ & 3256 & 6704 & & 5039 & 4912 & \\
\hline & $\geq 13 \mu \mathrm{mol} / \mathrm{L}$ & 248 & 303 & $0.56(0.43,0.72)$ & 246 & 303 & $0.86(0.63,1.16)$ \\
\hline
\end{tabular}

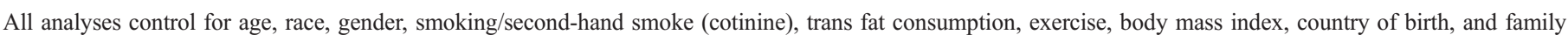
history of heart disease. In addition, the homocysteine model controlled for serum folate. National Health and Nutrition Examination Survey, $1999-2002$.

*Subjects over the age of 3 (except for fibrinogen, which are obtained only for subjects over the age of 40).

${ }^{\dagger}$ Subjects over the age of 25 (except for fibrinogen, which are obtained only for subjects over the age of 40).

${ }^{\star}$ Reference group $=<\$ 20,000$ or $<$ High school diploma. 
Table 3

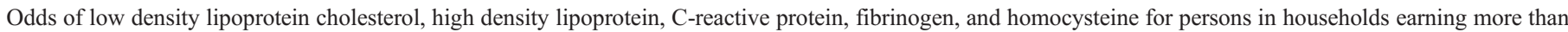
$\$ 20,000$ annually relative to those earning less than $\$ 20,000$ annually stratified by age

\begin{tabular}{|c|c|c|c|c|c|c|c|}
\hline \multirow[t]{2}{*}{ Age } & & \multicolumn{3}{|l|}{25 to $<65$} & \multicolumn{3}{|l|}{$65+$} \\
\hline & & $\begin{array}{l}\text { Income } \\
<\$ 20,000\end{array}$ & $\begin{array}{l}\text { Income } \\
\geq \$ 20,000\end{array}$ & $\begin{array}{l}\text { Odds ratio }(95 \% \\
\text { confidence limits)* }\end{array}$ & $\begin{array}{l}\text { Income } \\
<\$ 20,000\end{array}$ & $\begin{array}{l}\text { Income } \\
\geq \$ 20,000\end{array}$ & $\begin{array}{l}\text { Odds ratio }(95 \% \\
\text { confidence limits)* }\end{array}$ \\
\hline \multirow[t]{2}{*}{ Low density lipoprotein } & $<100 \mathrm{mg} / \mathrm{dL}$ & 132 & 400 & & 60 & 89 & \\
\hline & $\geq 100 \mathrm{mg} / \mathrm{dL}$ & 400 & 1235 & $0.94(0.65,1.37)$ & 237 & 314 & $0.78(0.47,1.30)$ \\
\hline \multirow[t]{2}{*}{ High density lipoprotein } & $<60 \mathrm{mg}$ & 956 & 2638 & & 510 & 669 & \\
\hline & $\geq 60 \mathrm{mg} / \mathrm{dL}$ & 247 & 855 & $1.23(0.94,1.62)$ & 166 & 265 & $1.66(1.13,2.39)$ \\
\hline \multirow[t]{2}{*}{ C-reactive protein } & $<1 \mathrm{mg} / \mathrm{L}$ & 250 & 984 & & 108 & 185 & \\
\hline & $\geq 1 \mathrm{mg} / \mathrm{L}$ & 956 & 2520 & $0.70(0.54,0.90)$ & 568 & 754 & $0.91(0.65,1.27)$ \\
\hline \multirow[t]{2}{*}{ Fibrinogen $^{\dagger}$} & $<300 \mathrm{mg} / \mathrm{dL}$ & 471 & 1524 & & 350 & 538 & \\
\hline & $\geq 300 \mathrm{mg} / \mathrm{dL}$ & 250 & 503 & $0.74(0.54,1.01)$ & 324 & 395 & $0.97(0.78,1.22)$ \\
\hline \multirow[t]{2}{*}{ Homocysteine } & $<13 \mu \mathrm{mol} / \mathrm{L}$ & 1120 & 3371 & & 533 & 788 & \\
\hline & $\geq 13 \mu \mathrm{mol} / \mathrm{L}$ & 83 & 127 & $0.60(0.41,0.88)$ & 143 & 150 & $0.62(0.43,0.90)$ \\
\hline
\end{tabular}

National Health and Nutrition Examination Survey, 1999-2002.

$*$ Reference group $=<\$ 20,000$.

${ }^{\dagger}$ Only subjects over age 40 .

were available) did not substantively alter the results. These results along with complete models can be found online at: http://www.pceo.org/stress.htm.

We found no evidence that C-reactive protein, fibrinogen, or homocysteine mediated the relationship between cholesterol values and SES in both unadjusted models and models that controlling for other known predictors of hypercholesterolemia.

\section{Discussion}

Using a large, nationally representative sample, we found a positive association between high blood levels of HDL cholesterol and both income and education. This relationship persisted after controlling for genetic and behavioral factors known to lower HDL cholesterol, including age, fat consumption, smoking, exposure to passive cigarette smoke, exercise, BMI, country of birth, gender, race, and a family history of heart disease. This analysis also controlled for the use of cholesterollowering medications, suggesting that the relationship persists even among those with access to medical care.

Likewise, blood homocysteine levels remained elevated among persons with low income even after controlling for blood folate levels. This helps rule out dietary factors as the lone contributor to differences in blood folate levels by income that we observed. Blood C-reactive protein levels - a compound thought to be associated with stress - were also elevated among those with lower educational attainment or income (Ridker et al., 2005; Steptoe et al., 2001; Owen et al., 2003).

Blood fibrinogen has been implicated as a contributor to heart disease, the leading cause of excess death among populations with low socioeconomic status (Markowe et al., 1985; Steptoe et al., 2003; Brunner et al., 1996; Goodman et al., 2005; Wamala et al., 1999; Wong et al., 2002). We found a trend toward higher fibrinogen levels among those with lower income and education, but these results were on the margin of statistical significance in this sub-sample of persons over the age of 40. In summary, we find good evidence that traditional behavioral and genetic risk factors probably do not account for the social class- related variations in blood levels of most of the substances we study here.

This analysis is subject to a number of limitations. Foremost, the data are cross-sectional. This prohibits an examination of the changes of blood levels of the stress mediators with age or with changes in social class. Second, most NHANES variables have been recorded into a small number of categories. Thus, both our linear and logistic regression models were less robust than they might have been had more categories or continuous data been available.

Finally, it is possible that analyses were confounded by unmeasured variables that explain the associations we found. While we controlled for all known causes of hypercholesterolemia in our analyses of blood cholesterol levels, and major potential confounders in the stress mediator analyses, it is not possible to conclude that low income or low education levels cause high levels of CRP, fibrinogen, or homocysteine (or low levels of HDL cholesterol). It is a larger jump still to directly implicate the stress mediators in heart disease. For instance, while homocysteine appears to be involved in the stress reaction, and is strongly associated with heart disease (Ridker et al., 2000; Jonasson et al., 2005; Guthikonda and Haynes, 1999), there is evidence that the association is not causal (Lonn et al., 2006). Other factors, such as blood cholesterol levels, are widely believed to be causally linked to heart disease.

Should a causal link between SES and blood levels of the biomarkers of stress we examined here be demonstrated, the linkage will have a variety of policy implications. Foremost, programs geared toward reducing community stressors, improving educational attainment, and improving earnings among low-income populations might conceivably have a larger impact on mortality than would be predicted by material deprivations alone. Stating health inequalities as a primary reason, the UK has again embarked on an ambitious program geared toward improving the quality of life and earnings potential of persons of lower SES (Acheson, 2002; Marmot, 2004; Roberts, 2000). Had environmental stressors been considered part of the puzzle in 
the design of earlier social welfare programs (such as public housing projects), it is conceivable that poverty would not have been so resilient in the UK and US.

Some successful policies produce a de facto reduction in environmental stressors. For instance, some education interventions improve educational attainment among those at risk of dropping out of high school (Finn et al., 2001; Karoly and Bigelow, 2005; Levin et al., 2006) while producing improvements in some measures of health and rates of crime (Schweinhart, 2004; Reynolds et al., 2001; Lleras-Muney, 2002). Reductions in crime, in turn, may have a multiplier effect on health if they simultaneously decrease injury and reduce neighborhood stress.

Finally, there is evidence that comprehensive community interventions can, in certain circumstances, lift people out of poverty and improve health (Geiger, 2002; Kling et al., 2004; Leventhal and Brooks-Gunn, 2003). Many successful interventions combine ideas traditionally associated with the political left with those associated with the political right. Indeed, we may be entering an age in which policy is driven both by an understanding of human incentives and empathy toward the plight of the poor. Designing public policies in such a way that they reduce stressors such as crime, low educational attainment, and unemployment is less politically controversial than measures that do not necessarily reduce stress, such as cash transfers, public housing, or other modalities that affect individual agency and require a good deal of paperwork.

To our knowledge, this is the first study to employ a nationally representative sample to examine stress mediators by family income and education, and the first to control for all known environmental and biological predictors of these mediators (save the variable of interest, stress).

However, there is more work to do. While longitudinal research is available for some markers, a birth cohort would help define those factors that give rise to elevations in these blood stress mediators and those that do not (Ridker et al., 2000). It well may be that, just as "good" and "bad" cholesterol levels effect heart disease risk, "good" or "bad" types of stress may differently affect blood cholesterol levels. For instance, the stress associated with running a Fortune 500 company may be qualitatively (and biologically) different from the stress associated with having a husband in jail, a leaky roof, and four children. Only with an understanding of the differences in such extreme scenarios, can we begin to understand the subtle differences in health risks across the socioeconomic spectrum.

\section{References}

Acheson, D., 2002. Independent Inquiry into Inequalities in Health Report. The Stationary Office, London.

Brunner, E., Davey Smith, G., Marmot, M., Canner, R., Beksinska, M., O’Brien, J., 1996. Childhood social circumstances and psychosocial and behavioural factors as determinants of plasma fibrinogen. Lancet 347 (9007), 1008-1013.

Cherkas, L.F., Aviv, A., Valdes, A.M., et al., 2006. The effects of social status on biological aging as measured by white-blood-cell telomere length. Aging Cell 5 (5), 361-365.

Davey Smith, G., Harbord, R., Ebrahim, S., 2004. Fibrinogen, C-reactive protein and coronary heart disease: does Mendelian randomization suggest the associations are non-causal? Qjm 97 (3), 163-166.
Epel, E.S., Blackburn, E.H., Lin, J., et al., 2004. Accelerated telomere shortening in response to life stress. Proc. Natl. Acad. Sci. U. S. A. 101 (49), 17312-17315.

Finn, J.D., Gerber, S.B., Achilles, C.M., 2001. The enduring effects of small classes. Teach. Coll. Rec. 103 (2).

Geiger, H.J., 2002. Community-oriented primary care: a path to community development. Am. J. Public Health 92 (11), 1713-1716.

Goodman, E., McEwen, B.S., Huang, B., Dolan, L.M., Adler, N.E., 2005. Social inequalities in biomarkers of cardiovascular risk in adolescence. Psychosom. Med. 67 (1), 9-15.

Guthikonda, S., Haynes, W.G., 1999. Homocysteine as a novel risk factor for atherosclerosis. Curr. Opin. Cardiol. 14 (4), 283-291.

Hosmer, David W., Lemeshow, Stanley, 2000. Applied logistic regression, Wiley Series in Probability and Statistics, 2nd ed. Wiley, New York.

Irie, M., Asami, S., Nagata, S., Miyata, M., Kasai, H., 2002. Psychological mediation of a type of oxidative DNA damage, 8-hydroxydeoxyguanosine, in peripheral blood leukocytes of non-smoking and non-drinking workers. Psychother. Psychosom. 71 (2), 90-96.

Jonasson, T., Ohlin, A.K., Gottsater, A., Hultberg, B., Ohlin, H., 2005. Plasma homocysteine and markers for oxidative stress and inflammation in patients with coronary artery disease-a prospective randomized study of vitamin supplementation. Clin. Chem. Lab. Med. 43 (6), 628-634.

Karoly, L.A., Bigelow, J.E., 2005. The economics of investing in universal preschool education in California. Rand Labor and Population. Santa Monica: Rand Corporation.

Kling, J.R., Liebman, J.B., Katz, L.F., Sanbonmatsu, L., 2004. Moving to opportunity and tranquility: neighborhood effects on adult economic selfsufficiency and health from a randomized housing voucher experiment. NBER: Working Paper Number RWP04-035.

Lantz, P.M., House, J.S., Lepkowski, J.M., Williams, D.R., Mero, R.P., Chen, J., 1998. Socioeconomic factors, health behaviors, and mortality: results from a nationally representative prospective study of US adults. JAMA 279 (21), 1703-1708.

Leventhal, T., Brooks-Gunn, J., 2003. Moving to opportunity: an experimental study of neighborhood effects on mental health. Am. J. Public Health 93 (9), 1576-1582.

Levin, H., Belfield, C., Muennig, P., Rouse, C., 2006. The Costs and Benefits of an Excellent Education for America's Children. Teachers College, New York.

Lleras-Muney, A., 2002. The relationship between education and adult mortality in the United States: NBER Working Paper No. 8986.

Lonn, E., Yusuf, S., Arnold, M.J., et al., 2006. Homocysteine lowering with folic acid and B vitamins in vascular disease. N. Engl. J. Med. 354 (15), $1567-1577$

Markowe, H.L., Marmot, M.G., Shipley, M.J., et al., 1985. Fibrinogen: a possible link between social class and coronary heart disease. Br. Med. J. (Clin. Res. Ed.) 291 (6505), 1312-1314.

Marmot, M.G., 2004. Tackling health inequalities since the Acheson inquiry. J. Epidemiol. Community Health 58 (4), 262-263.

McEwen, B.S., 1998. Protective and damaging effects of stress mediators. N. Engl. J. Med. 338 (3), 171-179.

Muennig, P., Franks, P., Jia, H., Lubetkin, E., Gold, M.R., 2005. The incomeassociated burden of disease in the United States. Soc. Sci. Med. 61 (9), 2018-2026.

National Health and Nutrition Examination Survey. 2005.

NCHS. National Center for Health Statistics. National Health and Nutrition Examination Survey. Available online at: http://www.cdc.gov/nchs. Accessed 6/20/05.

Owen, N., Poulton, T., Hay, F.C., Mohamed-Ali, V., Steptoe, A., 2003. Socioeconomic status, C-reactive protein, immune factors, and responses to acute mental stress. Brain Behav. Immun. 17 (4), 286-295.

Pfohl, M., Schreiber, I., Liebich, H.M., Haring, H.U., Hoffmeister, H.M., 1999. Upregulation of cholesterol synthesis after acute myocardial infarctionis cholesterol a positive acute phase reactant? Atherosclerosis 142 (2), 389-393.

Reynolds, A.J., Temple, J.A., Robertson, D.L., Mann, E.A., 2001. Long-term effects of an early childhood intervention on educational achievement and juvenile arrest: a 15-year follow-up of low-income children in public schools. JAMA 285 (18), 2339-2346. 
Ridker, P.M., Hennekens, C.H., Buring, J.E., Rifai, N., 2000. C-reactive protein and other markers of inflammation in the prediction of cardiovascular disease in women. N. Engl. J. Med. 342 (12), 836-843.

Ridker, P.M., Cannon, C.P., Morrow, D., et al., 2005. C-reactive protein levels and outcomes after statin therapy. N. Engl. J. Med. 352 (1), 20-28.

Roberts, H., 2000. What is Sure Start? Arch. Dis. Child 82 (6), 435-437.

Ross, C.E., Mirowsky, J., 2001. Neighborhood disadvantage, disorder, and health. J. Health Soc. Behav. 42 (3), 258-276.

Sapolsky, R.M., 2005. The influence of social hierarchy on primate health. Science 308 (5722), 648-652.

Schweinhart, L.J., 2004. The High/Scope Perry Preschool Study Through Age 40. High/Scope, Ypsilanti.

Smith, G.D., Shipley, M.J., Rose, G., 1990. Magnitude and causes of socioeconomic differentials in mortality: further evidence from the Whitehall Study. J. Epidemiol. Community Health 44 (4), 265-270.

Steptoe, A., Willemsen, G., Owen, N., Flower, L., Mohamed-Ali, V., 2001. Acute mental stress elicits delayed increases in circulating inflammatory cytokine levels. Clin. Sci. (Lond) 101 (2), 185-192.

Steptoe, A., Feldman, P.J., Kunz, S., Owen, N., Willemsen, G., Marmot, M., 2002a. Stress responsivity and socioeconomic status: a mechanism for increased cardiovascular disease risk? Eur. Heart J. 23 (22), 1757-1763.

Steptoe, A., Owen, N., Kunz-Ebrecht, S., Mohamed-Ali, V., 2002b. Inflammatory cytokines, socioeconomic status, and acute stress responsivity. Brain Behav. Immun. 16 (6), 774-784.

Steptoe, A., Kunz-Ebrecht, S., Owen, N., et al., 2003. Influence of socioeconomic status and job control on plasma fibrinogen responses to acute mental stress. Psychosom. Med. 65 (1), 137-144.

Sterling, P., Eyer, J., 1988. Allostasis: a new paradigm to explain arousal pathology. In: Fisher, S., Reason, J.T. (Eds.), Handbook of Life Stress, Cognition, and Health. Wiley, Chichester, New York.

Taylor, H., 2002. Poor people and African-Americans suffer the most stress from the hassles of daily living. Harris Poll 66 (http://www.harrisinteractive.com/ harris_poll/index.asp?PID=345).

Wamala, S.P., Lynch, J., Horsten, M., Mittleman, M.A., Schenck-Gustafsson, K., Orth-Gomer, K., 1999. Education and the metabolic syndrome in women. Diabetes Care 22 (12), 1999-2003.

Wong, M.D., Shapiro, M.F., Boscardin, W.J., Ettner, S.L., 2002. Contribution of major diseases to disparities in mortality. N. Engl. J. Med. 347 (20), 1585-1592. 